\title{
CD244 wt Allele
}

National Cancer Institute

\section{Source}

National Cancer Institute. CD244 wt Allele. NCI Thesaurus. Code C104069.

Human CD244 wild-type allele is located in the vicinity of 1q23.1 and is approximately 32 $\mathrm{kb}$ in length. This allele, which encodes natural killer cell receptor 2B4 protein, is involved in non-MHC-restricted NK cell killing. 